\title{
Digital advertising storytelling: consumer educommunication
}

\author{
$\mid$ \\ PhD. Rodrigo Elías Zambrano \\ University of Cadiz. Spain. \\ rodrigo.elias@uca.es \\ ORCID: http://orcid.org/0000-0001-8256-582X \\ DOI: http://dx.doi.org/10.12795/IROCAMM.2018.i1.02
}

\begin{abstract}
This is a revision of the concept of digital storytelling to get a definition from a point of view of consumer educommunication. This is how new digital advertising storytelling can modify consumer roles and behaviors.

So, in this text, we do a literature revision to explain the advantages of storytelling for digital marketing, the main common mistakes in digital advertising storytelling and what should a good storytelling strategy include. Besides, we make a description about media you have to use, the demand and growth of visual content and other digital marketing Trends for next years.
\end{abstract}

Keywords: Advertising; consumer; digital; educommunication; storytelling.
Resumen: El presente texto es una revisión del concepto de storytelling para alcanzar una definición desde el punto de vista de la educomunicación del consumidor. Esto es: cómo el actual storytelling publicitario digital puede modificar los roles y comportamientos de los consumidores.

De este modo, hacemos una revisión de la literatura para explicar las ventajas del storytelling para el marketing digital, los principales errores en el storytelling publicitario y que debería incluir una buena estrategia pensada por y para un storytelling. Asimismo, hacemos una descripción sobre los medios más adecuados para utilizar, así como la demanda y crecimiento del contenido visiaul $y$ otras tendencias del marketing digital para los próximos años.

Palabras clave: Consumidor; digital; educomunicación; publicidad; storytelling. 


\section{About digital advertising storytelling}

Digital storytelling, multimedia literature, digital narrative or even digital literature are different terms to describe the evolution of how to tell stories. The last ten years have meant a revolution in the systems of entertainment and information, causing us to rethink the use of these new means to find new forms of communication and how to transmit stories. Someone who wants to tell a story no longer has to just write, but has to know how to take advantage of the interactive possibilities of new digital media.

Storytelling emerged in the United States in the 1990s and has since become increasingly important in the world of communication, although it is affecting many other fields such as politics, education or consumption. And it is normal, because everyone likes to tell us stories (not only when we are children). You can convey your message among so many others being different, looking more personal and being closer.

Undoubtedly, advertising has been one of the disciplines that faster has acquired this fact to convey a discreet advertising message (Lundby, 2008). We could watch the example of this Spanish advertisement of Renfe:

\section{Image 1: Frame of Renfe tv spot}

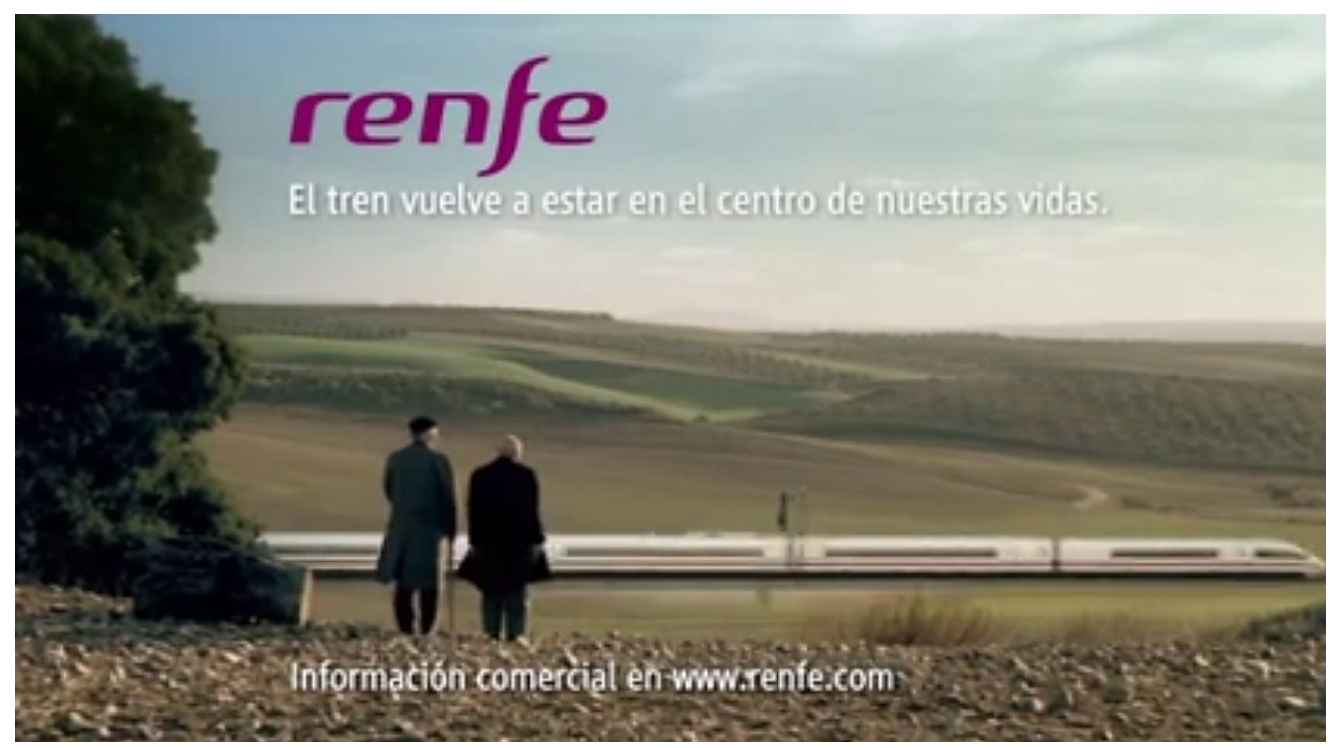

From: https://www.youtube.com/watch?v=vuL2y7k3a4o 
Digital narrative is something open since each user can choose what he wants to happen in the story according to their interests. In line with what Boumans (2004) brings, the writer / creator will have to design different itineraries that ramify the story with freedom and allow us to feel in real time what our characters live.

The possibility of interacting is the most innovative and stimulating aspect of the new media because apart from telling stories with text, photographs, radio, television or cinema... The Internet provides us with the dynamism and interactivity of objects, and it is something new that allows us to create

The main goal behind storytelling is in connecting with customers. It seeks closeness, empathy and connection with users who are not willing to continue consuming products as before. Marketing seeks a new way of communication that allows the same, but in another way, so as to be able to highlight the product for new consumers (Jiménez-Marín, Pérez and Elías, 2014).

Because the ability to tell stories seeks that emotional connection that is so much used in today's marketing. The use of storytelling is transversal to the different ways of doing marketing. This form of marketing can be used in emailing, newsletters, landing pages, spots, banners, retargeting, SMS or social networks. And they are, precisely, social networks, the place where this form of communication has proliferated based on experiences and small stories.

It is said that a digital story for marketing (advertising storytelling) has to have three fundamental components (Bourdaa, 2012):

1. Hypertext: nonlinear reading of speech

2. Multimedia: use of different media: animations, audio, video...

3. Interaction: the user can choose and execute in the system its own actions.

The writer / creator (or creative writer) is going to assume different roles than those of a traditional writer, he will have to perform new functions much more technical: writing, information manipulation, multimedia application management, graphic and collaborative design with design professionals or programming. 


\section{Advantages of storytelling for digital marketing}

Social networks have fostered a form of communication based on the 'I have something to tell you' principle. The communication format based on influencers, bloggers, instagramers or youtubers has made it easier for storytelling to become something everyday (Ramos and Jiménez-Marín, 2014). Its ability to connect with the public has raised this technique to a new dimension. Its potential is enormous, and its connection capacity is greater than with a traditional "buy my product" message. In a scenario where users feel saturated with marketing, looking for new forms of communication that break the usual market trend is the ideal solution.

So, what are the specific advantages of digital storytelling for marketing and advertising? As Berelowitz et al (2012) claim:

- Connects better with customers: It's a different way of directing users to get these users to pay more attention to what you tell them.

- It will give your own identity mark: Your stories will be yours, there will be no one who can tell the same. Your communication will become totally personal and unique. It will help you to differentiate yourself from the competition and place your brand as a benchmark in the sector.

- Help customers better identify your brand: They will remember what you say and how you say it. A brand that chooses a message where it has something more to tell than its desire to buy its products is an identifiable brand. It is important to implement a system that will differentiate you and be an element that customers can identify among others. Your brand will benefit by choosing a different way of doing marketing.

- Updates the brand image: Storytelling is the way to tell stories of the 21st century. It has triumphed in social networks and is the form of marketing that likes the young people. Using this technique in your marketing strategy will allow you to update your brand image and renew the perspective that users and buyers have of you.

- It is applicable to all media: Storytelling has the great advantage of being a form of transversal communication. It is applicable to all digital marketing media. Its potential is perceptible since it is used in landings, emails, banners or social networks alike. It is a totally novel way of telling things. It is not complicated to use, but requires planning enough to avoid errors. 


\section{Common mistakes in advertising digital storytelling}

Storytelling is a very effective form of communication, but it requires careful planning. It is important to elaborate this technique well not to fall into the usual mistakes that can be given: From the authos Lundby (2008) and Martin (2011) we extract:

- Contrary to the message: This comes from cinema language. This form of marketing has strength when the message and the transmitter of the message are counting the same. The contradiction between message and speaker makes this technique lose power. Thus, if a model used to tell a happy story transmits sadness with its gaze, it will be a contradictory message and nothing valid.

- Lie: Along with contradiction is the most common mistake. The Spanish proverb says that a liar is caught before a lame, and he is right. If your brand has a number of preconceived elements, principles and ideas, it is bad to go against them. You can try to paddle, but users will perceive that you are lying. If your brand or product conveys a specific idea, you should promote it, and not try to sell something that is not.

- Failure in tone: Storytelling is a resource that makes it easy to use humor and satire to sell. It is a habitual resource, which weakens the environment and facilitates a greater client-brand connection. The tricky thing about this is being able to find the right tone to convey the message. Humor is a very complicated resource to employ, almost more than drama. You must be careful about the joke or comment you employ and know what tone really benefits your brand.

- Force reaction: This technique allows you to strengthen the client-brand connection, but it is a double-edged sword. You can't force the reaction of your customers, you can't force the sense of urgency. Everything must be implied in the message. If you force a reaction you will lose the power of the message.

\section{So, what should a good storytelling strategy include?}

As Garrido (2013), Bourdaa (2012) and Lehu (2007) contribute, for this technique triumph it must incorporate essential elements:

- Brand values: You must be able to convey the principles on which your brand is built. Your brand values are necessary if you want to connect with 
the customer. In addition to the emotional issue, important, it is also important to say how you are and what you offer.

- Emotion: Emotion is the main resource behind storytelling. At the end, it seeks to connect with the client, make something move inside it and end up consuming. You must be able to employ language based on emotions. Your goal is to end your speech by captivating the customer, by calling attention to him to buy. Emotion can be positive (joy or happiness) or negative (pity or pity). Each brand has to opt for some kind of emotion that they want to convey to the customer. But keep in mind, your brand will be identified with that chosen emotion.

- Product strengths: Just as you power your brand image through the positive aspects or your brand values, you must be able to highlight the product or service you offer. Emphasize the good thing about buying your idea.

- Something that engages: Along with emotion, your speech must be able to articulate in a way that engages the client. Your story should captivate and attract the attention of the public. If it catches your eye and gets buyers to be aware, you will have succeeded. Hooking on your stories, your stories, is the goal behind storytelling. It draws attention and captivates customers by hooking them to what you have to tell.

\section{Media you have to use}

While there are examples of brands that use storytelling in their emailing or landing pages, it is television that has taken a step forward and has been shown as the setting for this technique par excellence. The advertising spots of brands like international Ikea or, for example, the Spanish company Campofrío are examples of brands that use storytelling effectively.

Image 2: Ikea Spot

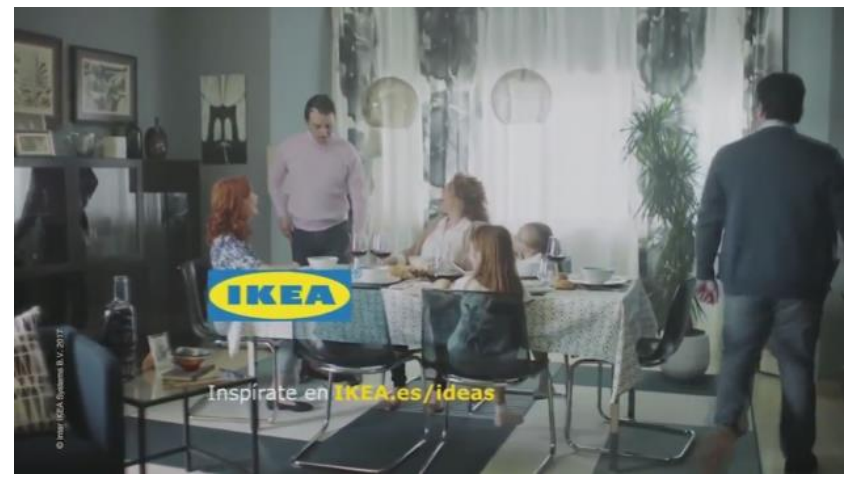

From: https://www.youtube.com/watch?v=EtSAO8-bi6w 


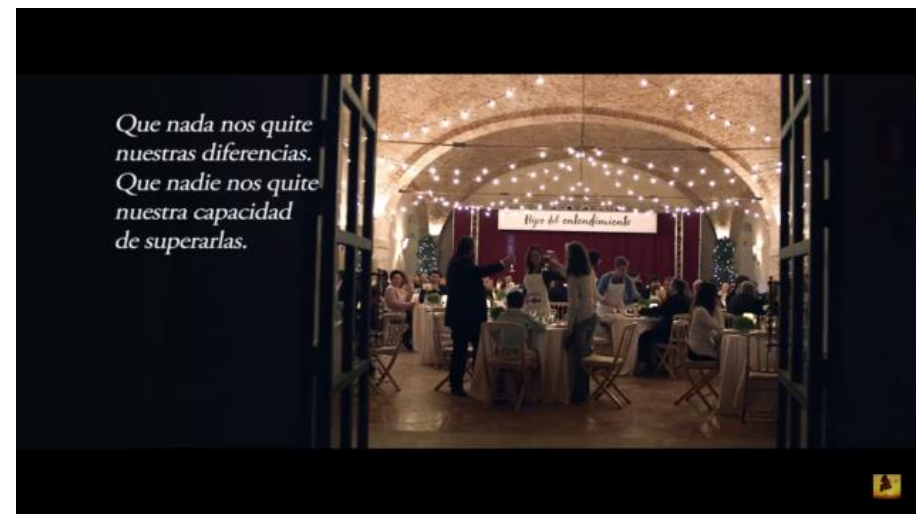

From: https://www.youtube.com/watch?v=Imx00hOw8HY

All these brands use a common denominator, create a story and a spot to illustrate. Its potential comes from combining daily stories in ad format, which may well be short. Its quality of production and freshness makes them stand out among other brands that are advertised in the same advertising space.

But if there is a brand that has excelled as an expert in storytelling is the Spanish Balay. The Spanish brand of electrical appliances has included this technique during the last years to promote its branding. Its workers have become the brand image. The daily stories and the testimonies of the workers in charge of creating washers, refrigerators or kitchens is the great strength of these spots.

\section{Image 4: Balay spot}

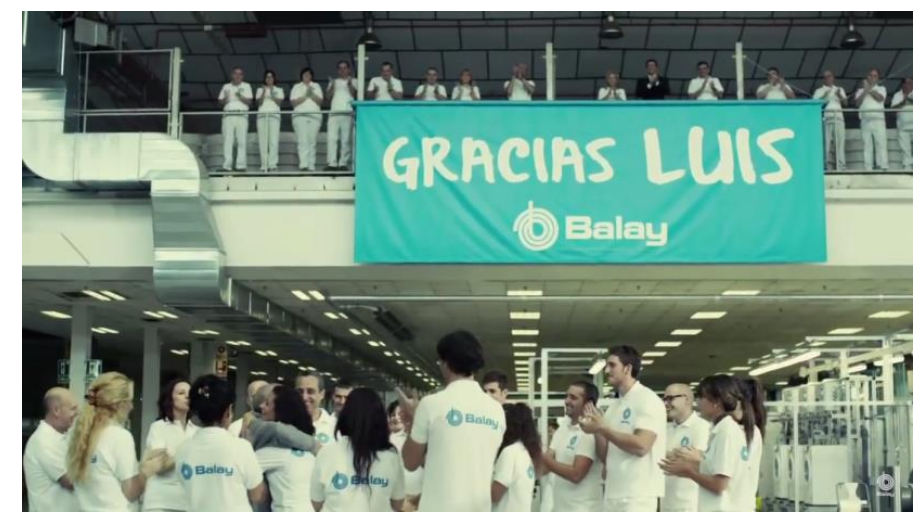

From: https://www.youtube.com/watch?v=Dwj8F6sIrw0

\section{The demand and growth of visual content}


It's already clear that the demand for visual storytelling in the content marketing industry is going to see tremendous growth in next years. This is predicated on the fact that content generates up to 94 percent more views when compelling visual elements are incorporated (Papandrea, 2017).

However, if you're going to invest in visual storytelling and maximize its potential, you need to know what you're doing. As content marketer Papandrea (2017) points out, "you can't simply slap a few stock photos onto your blog or social media posts. Just as headlines and calls to action must be crafted carefully, your visual content deserves more than a second thought.". Because if you want to "nail visual storytelling," as Papandrea (2017) says, you need to focus on authenticity, sensory, and relevancy. So, in a society that comes from the information society and that is already immersed in a digital society (Silva, Jiménez-Marín and Elías, 2012), in order to do this, it is necessary to keep the following points in mind:

- YouTube stands alone: From a visual storytelling point of view, no platform is as powerful as YouTube. It's the world's second-largest search engine and gives brands the opportunity to deliver powerful content to massive audiences.

- The rise of interactive visual storytelling: Look for interactive visual storytelling to become a highly pursued strategy for big brands. Papandrea (2017) calls this a hybrid form of interactive content, in the sense that it contains multiple unique elements of visual storytelling in a single, consolidated medium.

- Virtual reality will put another foot forward: Mass adoption of virtual reality (VR) technology - both on business and consumer sides - is still a couple of years away. Trendy brands will try to make a splash by leveraging new VR tools at events and physical retail locations. Tommy Hilfiger brand, for example, recently did this when launching their 5th Avenue store in New York City.

Image 8: VR for Tommy Hilfiger store in New York.

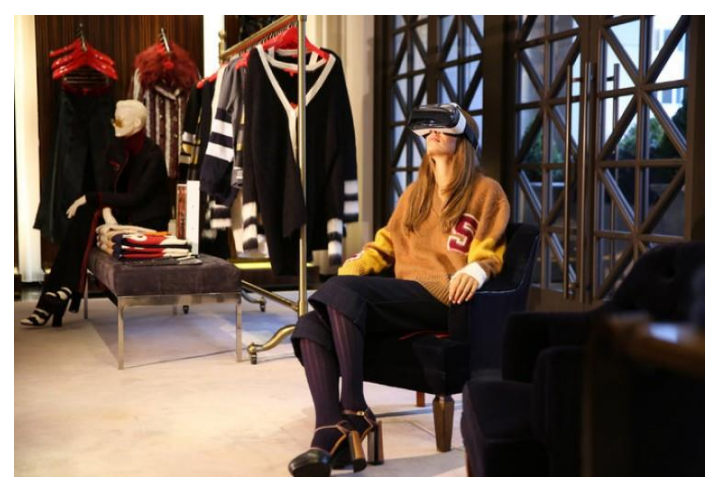

From: http://www.bandt.com.au/media/tommy-hilfiger-introduces-in-store-virtual-reality-experience

\section{Other Digital Marketing Trends for the}




\section{next future}

While visual storytelling will probably highlight the top digital marketing trends of 2017 and next years, there are certainly some other developments worth monitoring. Papandrea (2017) considers:

- Increased emphasis on analytics: As businesses begin to spend more on digital marketing, the amount they spend on analytics is also expected to rise, according to some calculations.

- Growth of live stream social: One of the biggest developments in the social media industry is being the introduction of a new social medium: live stream social. Platforms like: Periscope, Facebook on streaming, Instagram live and Meerkat have taken the market by storm.

- Even more micro targeting. As advertising platforms like Facebook and Google gain access to more user information and trends, the ability to micro target paid advertising efforts will be greatly enhanced. Facebook already has plenty of targeting options, but look for things to improve even more in the coming months.

- Content for wearables. The Apple Watch hasn't been quite the success brand officials were hoping, but it also hasn't been a total flop. There will be significant growth in the wearable device market for next years, which naturally means savvy digital marketers need to prepare content for these new devices.

\section{Conclussions}

The proliferation of digital marketing technology is happening at an astounding pace. In fact, it gets faster and faster each year. Look for digital marketing -and content marketing in particular- to undergo some significant shifts. Visual storytelling will lead the way, but don't forget about the other trends and issues. It'll be the brands that are constantly monitoring new developments that see the most success next years.

\section{Documentation}


Berelowitz, M. et al (2012). 10 Ways Marketers are Using the Second Screen. JWT Intelligence, New York.

Bourdaa, M. (2012) 'Transmedia: Between augmented storytelling and immersive Practices', Inaglobal, 6 September.

[Accessible at http://www.inaglobal.fr/en/digital-tech/article/transmediabetweenaugmented-storytelling-and-immersive-practices.] Accessed June 2017.

Bourdaa, M. (2012) "This is not Marketing. This is HBO: Branding HBO with Transmedia Storytelling". Networking Knowledge 7(1).

Boumans, J. (2004). "Cross-media, e-content report 8, ACTeN - Anticipating content technology needs".

[Accessible at http://www.acten.net/cgi-bin/WebGUI/www/index.pl/cross_media]

Galician, M. (Ed.). (2004). Handbook of product placement in the mass media. New York: Haworth.

Garrido, A. (2013). "¿Cómo aplicar el Storytelling a una campaña de marketing? Una nueva forma de entender la evolución del marketing de contenidos" Puro Marketing, [Accessible at: http://www.puromarketing.com/10/18647/como-aplicar-storytellingcampana-marketing.html] Accessed June 2017.

http://www.bandt.com.au/media/tommy-hilfiger-introduces-in-store-virtual-reality-experience. Accessed March 2017.

http://dawnpapandrea.com/. Accessed March 2017.

Iacobacci, N. (2008). "From crossmedia to transmedia: thoughts on the future of entertainment".

[Accessible at http:www.lunchoverip.com/2008/05/from-crossmedia.html]. Accesed May 2017.

Jenkins, H. (2007). "Transmedia storytelling".

[Accessible at: http://www.henryjenkins.org/2007/03/transmedia_storytelling_101.html]. Accessed March 2017.

Jiménez-Marín, G; Pérez Curiel, C; Elías Zambrano, R. (2014): "Del valor educativo de los medios de comunicación: una aproximación al caso audiovisual". Ámbitos Review. International review of communication, n.25, 2014, summer.

Lehu, J. M. (2007). Branded entertainment: Product placement \& brand strategy in the entertainment business. London: Kogan Page.

Lundby, Knut (2008): Digital storytelling, mediatized stories. Self-representations in new media. New York, Peter Lang Publishing, 
Martin, C., (2011), The Third Screen: Marketing to your Customers in a World Gone Mobile, Nicholas Brealey Pub.

Mittel, J. (2010) 'Serial Boxes', Just TV, [blog], 20 January.

[Accessible at http://justtv.wordpress.com/2010/01/20/serial-boxes/]. Accessed May 2017.

Nielsen, (2014), The Digital Consumer Report. [Accessible at http://www.cdmn.ca/wpcontent/uploads/2014/02/the-digital-consumers-report-feb-2014.pdf.]. Accessed April 2017.

Ramos Serrano, M. y Jiménez-Marín, G. (2014): "Blogs y Moda: cuando los usuarios crean las tendencias" en Fernández-Quijada, D. y Ramos Serrano, M.: Tecnologías de la persuasión. Uso de las TIC en publicidad y relaciones públicas. Barcelona, UOC. ISBN: 9788490644713. pp. 131-143.

Ross, S.M. (2008). Beyond the box: Television and the Internet. Malden (MA): Wiley-Blackwell.

Scolari, C. A. (2009). "Transmedia Storytelling: Implicit Consumers, Narrative Worlds, and Branding in Contemporary Media Production". International Journal of Communication, 3, 586-606.

Scolari, C. (2008). "Online brands. Branding, possible worlds and interactive grammars". Semiotica 169(1/4), 143-162.

Silva Robles, C.; Jiménez-Marín, G.; Elías Zambrano, R. (2012): "De la sociedad de la información a la sociedad digital. Web 2.0 y redes sociales en el panorama mediático actual". F@ro review, N015 (2012). Facultad de Ciencias Sociales, Universidad de Playa Ancha Valparaíso, Chile. 